\title{
APPRECIATING BUILT HERITAGE THROUGH URBAN SENSORY ELEMENTS
}

\author{
Rosilawati Zainol ${ }^{1}$ \\ Faizah Ahmad ${ }^{2}$ \\ Nikmatul Adha Nordin ${ }^{3}$ \\ Ibrahim Mohd @ $\mathrm{Ahmad}^{4}$ \\ Goh Hong Ching ${ }^{5}$ \\ ${ }^{12}{ }^{34}$ Department of Urban and Regional Planning, Faculty of Built Environment, University of Malaya \\ ${ }^{5}$ Department of Geography, Faculty of Arts and Social Sciences, University of Malaya
}

\begin{abstract}
Many heritage cities have been turned into tourism cities. With the influx in the number of foreign tourists together with the number of locals, mobility within these cities has become a challenging issue to be dealt by the city managers. Taking into cognizance the global warming and climate change, the most appropriate mode of transportation that considers these issues and simultaneously appreciates the urban aesthetics and heritage tourism products in a heritage city needs to be identified. Therefore, this study seeks to identify the most appropriate mode of transportation that incorporates carbon footprint mitigation, urban sensory elements and tourists' satisfactions components. Data were collected through participant observation were analyzed. Geographic information systems (GIS) application is used to analyze the study area spatially. The findings demonstrate that walking is the most appropriate as it is able to satisfy tourists in appreciating urban sensory elements and simultaneously mitigate carbon footprint. The study concludes that in order to sustain heritage cities and handling global warming issues simultaneously, future development in these cities should be strictly controlled and monitored and the use non motorized vehicles such as bicycles and trishaws other than walking should be promoted within these cities.
\end{abstract}

\subsection{Introduction}

Tourism and climate change are interlinked in a complex manner. Although scientific papers on issues related to this linkage were published in the 1980s (McBoyle \& Wall, 1987; McBoyle et al., 1986; Wall et al., 1986), it was not considered as crucial until recently (Gössling, 2011). Climate change became politically important in the Fourth Assessment Report (FAR) which was published in 2003 when it covers issue of the impact of climate change has on tourism (Gössling, 2011). The first International Conference on Climate Change and Tourism in Djerba, Tunisia in 2003 focuses on tourism adaptation in facing climate change (Gössling, 2011; OMT-WTO-BTO, 2003). Nevertheless, this conference acknowledged that tourism affects and being affected by climate change. In addition, this conference has led to Djerba Declaration, 2003 which acknowledged the complex interlink between tourism and climate change (Gössling, 2011; OMT-WTO-BTO, 2003). This is followed by Davos Declaration, 2007 which discuss further on strategies in mitigating interlink effects of climate change on and from tourism. These include formulating policies and promoting sustainable tourism (Gössling, 2011).

Carbon management in tourism is becoming an important topic currently due to world sensitivity towards the environment. According to United Nation World Tourism Organization (UNWTO)'s report, tourism contributes 5\% of global carbon emission (Gössling, 2011; UNWTO-UNEP-WMO, 2008). Contributors from tourism sector include 
transportation, $75 \%$, accommodation, $21 \%$, and activities, $4 \%$. In transportation, air transport contributes the highest carbon emission which constitutes about 40\%, followed by car, 32\% and other transport, 3\% (Gössling, 2011; UNWTO-UNEP-WMO, 2008). Other transport consists of train, coach and trams.

In view of the importance of carbon management in tourism, it is timely that new method be introduced to tackle carbon footprint issue in heritage cities which at the same time have become the centre of tourists' attractions. Heritage cities were designed with few motorized vehicles and walkable friendly environment. Therefore, this study's objectives are to identify heritage areas in Melaka Historical City, to evaluate tourist's appreciation of urban sensory elements on the heritage tourism products and to identify the best method of appreciating urban sensory elements whilst reducing carbon footprints.

This paper is structured in six sections. Section two sets the conceptual framework of the study. In section three, methodology of the research is described. The fourth section describes the study area. In section five, results of the study are presented. The paper ends with discussion and concluding remarks in section six.

\subsection{Carbon Management, Urban Sensory Elements and Tourists' Satisfaction}

Carbon management, urban sensory elements, heritage tourism products, expectancy-disconfirmation theory and mode of transportation form the conceptual framework in this study (Figure 1). Geographic Information Systems (GIS) application is used to combine these elements to form the best mode of transportation in managing carbon footprint and at the same time appreciating the urban sensory elements and heritage tourism products satisfactorily.

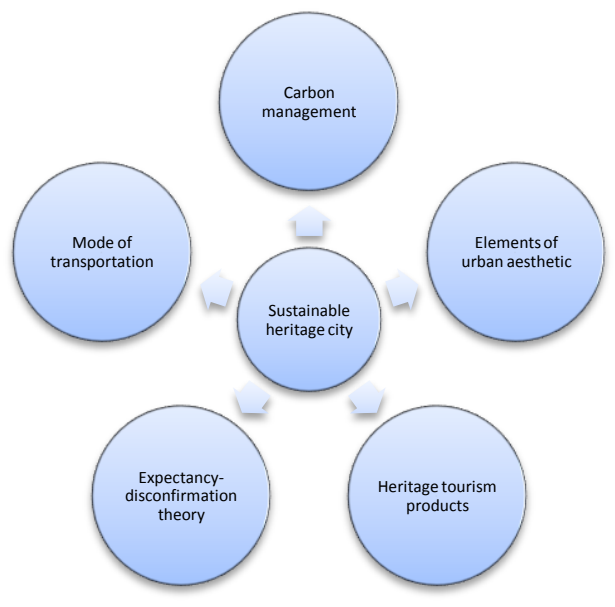

Figure 1: Study's Conceptual Framework 
Carbon management in tourism was not seriously looked into until 2007 when UNWTO called for a reduction in carbon emission in tourism. Davos Declaration called for government and international organizations to take part in reducing Greenhouse Gas (GHG) and called for tourism industry and destination to take leadership in implementing strategies to mitigate climate change (UNWTO, 2007). Tourists are also asked to consider climate change while planning for vacation and participate in activities that will reduce carbon footprint. In addition, researchers and communication networks are encouraged to develop tools for risk assessment and cost benefit analysis, to include climate change and carbon mitigation in tourism training curriculum and promote sustainable tourism (UNWTO, 2007).

Aesthetic value of a city is a combination of sensory stimuli and can be appreciated mainly by slow pedestrians and with day time effect (Burchard, 1957; Forsyth \& Southworth, 2008). Therefore, in appreciating urban sensory elements, Burchard (1957) has outlined five basic elements. These elements are sight/visual, smell, noise, history and feel/taste. With sight/visual, appreciating urban sensory elements is not limited to architectural design but also the people and the design of the area. Architectural design reflects the cultural background of an area. The ways local people dress also reflect the culture too. In addition, the design of an urban area provides sense of comfort and safety of its inhabitants. Similarly, smell can reflect an image of a city. It can be smell of food, main product of a city such as coal, or smoke for polluted city. Nevertheless, noise can symbolize a city too. It could be the sound of animals, clock tower chimes, motor vehicles and people talking loudly. History tells the background of a city and how it is designed and developed. Melaka, for example, has its own history that is told by the variety of buildings and architecture available in this city. Feel/taste, on the other hand, symbolizes the comfort the city's environments are able to provide such as heat and shade.

Heritage tourism is defined as a leisure trip to experience places, artifacts, and activities that represent the historic, cultural and natural attractions and peoples of the past and present of a destination (Dunlap et al., 2001; Wisconsin Department of Tourism, 2011). Tourists may experience what have been left by the past of a destination by examining the details of structures and monuments. Preserving and conserving heritage tourism products demand collectable efforts among stakeholders (Andreanne, 2010). State government, local authority, heritage organizations and agencies and last but not least the local residents have to work together in making these efforts successful. In Malaysia, Georgetown and Melaka are considered as living heritage cities (Andreanne, 2010). This is due to the existence of local residents who are constrained to living within rules and regulations that do not allow them to make changes to their properties. Some local residents are also participants as they are required to open their homes to visitors through home-stay program as evidenced in Kampung Morten. Some concerns have been raised on the effects of this representation to their inhabitants. Moreover, United Nations Educational, Scientific and Cultural Organization (UNESCO)'s declaration on Georgetown and Melaka as world heritage sites has definitely increased the number of tourists visiting these two cities (Chua, 2008; VanBlarcom \& Kayahan, 2011). This has indirectly boost the economic revenue of both cities (VanBlarcom \& Kayahan, 2011). With the influx in the number of foreign tourists together with the number of locals, mobility within these cities has become a challenging issue to be dealt by 
the city managers. As a result, congestion is inevitable. Therefore, steps need to be taken ease traffics in world heritage cities. These steps among others include creating non-motorized zone around the world heritage areas, using trams and public buses to transport people from places outside the city to the city center, reclaiming road to create more pedestrian walkway and building multiple stories car parks outside the city to encourage people to use public transportation.

Tourist's satisfaction is a tool in increasing destinations competitiveness (Andriotis et al., 2008). In this study, tourist's or consumer's satisfaction is measured against heritage tourism products that they come across in Melaka Historical City. Many studies have been carried out to measure consumer's satisfaction (Fornell, 1992; Oliver, 1980). Models such as American Customer Satisfaction Index (ACSI), Swedish Customer Satisfaction Barometer (SCSB), German Barometer, Norwegian Customer Satisfaction Barometer (NCSB) and Malaysian Customer Satisfaction Index (MCSI) are among others (Yang et al., 2011). Yang et al. (2011) compare four influential national CSIs from two perspectives: latent and manifest variables in said CSI models and the relationship between latent variables. Results show that consumer's expectation as latent variable has different influences in other constructs in various CSI models. This is due to the various types categories used in measuring products or services. Consumer's satisfaction can also be measured using a factor cluster segmentation approach (Andriotis, et al., 2008). In this approach, tourist's satisfaction is measured based on tourist's group distinct segments, socio-demographic and travel arrangement characteristics. The differences between these are then measured against three clusters: 'highersatisfied', 'in-betweeners' and 'lower-satisfied' (Andriotis, et al., 2008:227). Identifying tourist's segmentation and clusters may assist marketers in designing marketing strategies to bring more tourists to a destination. One of the most common approaches used in measuring consumer's satisfaction is expectancy-disconfirmation. Expectancydisconfirmation theory is used to measure consumers' satisfaction on products or services that they use based on their expectation and acknowledgement (Johari, 2010; Oliver, 1980). Mooted by Oliver (1980), this theory uses expectation as a baseline in comparing performance of a product. If a consumer matches or exceeds his expectation as perceived earlier with the product's performance, then a direct and positive effect on satisfaction is achieved respectively. However, if the expectation is not met then a negative disconfirmation has occurred. This will lead to consumer's dissatisfaction and sale of the product might not recur in the future. Studies on tourists' satisfaction follow this trend too. Tourists' satisfaction is measured by expectation and experience. If the experience ends with a feeling of happiness and this match or exceeds the expectation, satisfaction has been achieved. However, if at any point tourists feel dissatisfied with the services offered and beyond their expectation, a feeling of displeasure and disappointment will occur. This could lead to a point of no return.

Geographic information systems (GIS) is an information system that can capture, store, manipulate and display georeferenced data (Al-Sabhan, 2003; Chang, 2008; Heywood et al., 2002; Worboys, 1995). This application has been around since 1960s. However, it became fully computerized in late 1980s. This system has gone through various stages of evolution starting from being paper-based map, stand alone computer system, stand alone with graphic user interface (GUI) computer system, web-based, 3D and recently network computer system (Coppock \& Rhind, 
2011; Hoel et al., 2010). GIS application is used in various disciplines that require spatial analysis such as urban planning and management, tourism planning and management, history and education among others.

\subsection{Methodology}

In achieving the research objectives, geographic information systems (GIS) application is used to identify heritage areas in Melaka Historical City spatially and participant observation technique is used to evaluate tourist's appreciation of urban sensory elements on the heritage tourism products and to identify the best method of appreciating the said elements and at the same time reduce carbon footprint. In addition, Buchard's elements of urban aesthetics are used as indicators to evaluate the conditions of the study area. The elements include sight, noise, history, smell and taste (Burchard, 1957). Nevertheless, expectancy-disconfirmation theory is used as measurement method in this evaluation. The scale measurement ranges from 0 as inaccessible, 1 being worse than, 2 being equal and finally 3 being better than what is expected. The total score will be deducted if there is any cost incur in using the mode of mobility. The rubric for this measurement is laid in Table 1.

Table 1: Measurement Rubric

\begin{tabular}{|l|l|l|l|l|}
\hline \multirow{2}{*}{ Scale } & 0 & 1 & 2 & 3 \\
\cline { 2 - 5 } $\begin{array}{l}\text { Sensory elements } \\
\text { being appreciated }\end{array}$ & $\begin{array}{l}\text { Inaccessible } \\
\text { elements are } \\
\text { inaccessible }\end{array}$ & $\begin{array}{l}\text { Being worse than } \\
\text { Sensory elements can } \\
\text { be appreciated }\end{array}$ & $\begin{array}{l}\text { Being equal } \\
\text { five to three of the } \\
\text { elements can bensory } \\
\text { appreciated }\end{array}$ & $\begin{array}{l}\text { All the five sensory } \\
\text { elements can be } \\
\text { appreciated in detail } \\
\text { be }\end{array}$ \\
\hline Cost (-ve) & No cost incur & Cost is small & Cost is medium & Cost is high \\
\hline $\begin{array}{l}\text { Carbon footprint } \\
\text { ve) }\end{array}$ & No carbon footprint & $\begin{array}{l}\text { Small amount of } \\
\text { carbon footprint }\end{array}$ & $\begin{array}{l}\text { Medium amount of } \\
\text { carbon footprint }\end{array}$ & $\begin{array}{l}\text { High amount of } \\
\text { carbon footprint }\end{array}$ \\
\hline
\end{tabular}

Nonetheless, in evaluating the conditions of the study area, five methods of mobility are used. Firstly is by using a car. Secondly is by using public bus, followed by river transport, trishaw, riding bicycle and finally by walking. In evaluating Melaka River, river cruise using tourist's boat, riding bicycle and walking are chosen. Buchard's elements of urban aesthetics are used as indicators for each method.

In addition, GIS data source, wikimapia, is used as based map in this study. A spatial database that contains four layers namely heritage attractions, road network, pedestrian walkway and water body are developed. Each layer has specific attributes that allows spatial analysis to be conducted easily.

\subsection{Study Area}

Melaka Historical City is a tourist's destination that posses handful types of tourism products. Heritage, shopping, health, nature, and food are among the products that available in this historical city. However, its image as a historical city with its heritage products outshines the others. This is due to its status as world heritage sites. Melaka 
received its historical city status in 1989 (Andreanne, 2010; Johari, 2010) and listed as World Heritage Site by UNESCO in 2008 (Chua, 2008). The areas that are included in the world heritage sites are areas near St Paul's Hill, the $17^{\text {th }}$ century Dutch Stadhuys, Jonker Street, Jalan Tukang Besi, Kampung Morten and Melaka River. The world heritage sites near St Paul's Hill include Stadhuys Historic Museum, Democratic Government Museum, Cheng Ho Gallery, Literature Museum, Architecture Museum, Islam Museum, UMNO Museum, Ethnography Museum, Kite Museum, Stamp Museum, Bastion House, Muzium Dunia Baru Dunia Islam, A'Famosa, Malacca tree, Proclamation of Independence Memorial, Historic City Memorial Garden, Malacca Sultanate Palace, Dutch Graveyard, the Governor Museum and finally St Paul's Hill. Therefore, the study area is limited to the areas that are listed in the world heritage sites. Figure 2 shows the core zone which is the study area and partial of buffer zone of the Melaka Historical City (Melaka Historical City Council, 2007).

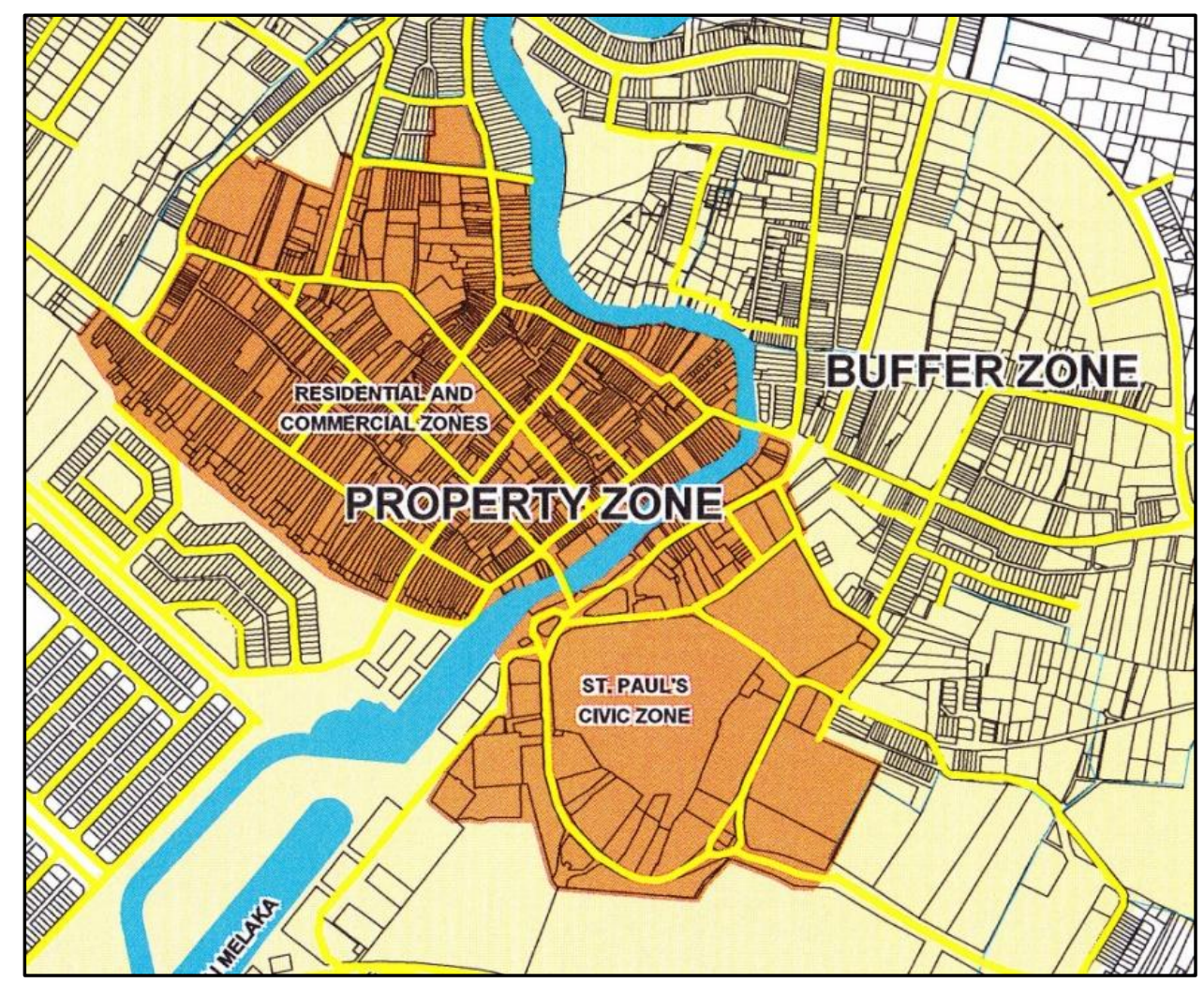

Figure 2: Core and partial of Buffer Zones of Melaka Historical City

(source: Melaka Historical City Council, 2007)

\subsection{Findings}

Findings have shown that Melaka has priceless number of heritage products. These products are located near to each other in the heart of the city that can symbolize Melaka as the birth of a nation in which Melaka was once being the trade and maritime centre in addition to an early Malay city state in the $14^{\text {th }}$ century (Refer Figure 3). 
Using GIS application, the distance between historical buildings and monuments can be measured easily. Furthermore, this application is able to show the areas that are accessible by car, trishaw and walking. The distance within the world heritage sites near St Paul's Hill is around one kilometer. Nevertheless, the areas along Jonker Street and Jalan Tukang Besi are within one kilometer too. Similarly in Kampung Morten, areas within this heritage site are within one kilometer.

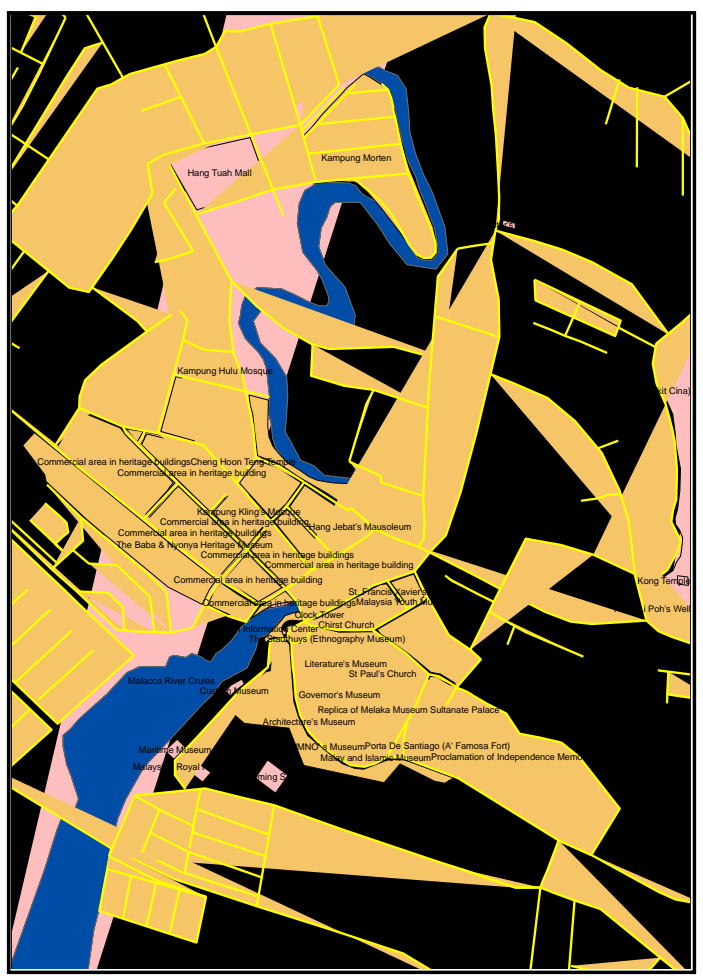

Figure 3: Distribution of Attractions in Melaka Historical City

Urban heritage sensory element is appreciated through observing details. Findings show that by using car, elements of urban sensory can only be viewed from far, no smell, feel and noise can be captured, no appreciation on historical building or sites and there is no place to stop to actually taste or feel what is being offered in study area. Furthermore, car is only accessible around Jonker Street, Jalan Tukang Besi and Kampung Morten. Areas around St Paul's Hill, Melaka River and the $17^{\text {th }}$ century Dutch Stadhuys can only be accessible through walking and trishaw services. Therefore, the only thing that can be appreciated using this method is through sightseeing from far that is from inside the car. In addition, a car contributes more of carbon footprint and it costs higher since a car has to make big circles to reach their destinations since there are a lot of one way streets in Melaka Historical City due to narrow streets. 
In addition, riding on a public bus does not allow tourists to appreciate the urban sensory elements. It may not cost much, but it is not flexible. Tourists have to stop at a bus stop and walk to their destinations which might be located quite far (more than one kilometer). Furthermore, it contributes to the carbon footprint.

Table 2: Five Sensory Measurement using various modal of transportation

\begin{tabular}{lllllllll}
\hline & Sight & Noise & History & Smell & Taste/Feel & Cost (-ve) & $\begin{array}{l}\text { Carbon } \\
\text { Footprint (-ve) }\end{array}$ & Total \\
\hline Car & 1 & 0 & 0 & 0 & 0 & -2 & -2 & -3 \\
Public Bus & 1 & 0 & 0 & 0 & 0 & -1 & -1 & -1 \\
River Cruise & 1 & 1 & 1 & 1 & 0 & -2 & -1 & 1 \\
Trishaw & 1 & 1 & 1 & 1 & 1 & -3 & 0 & 2 \\
Bicycle & 1 & 1 & 1 & 1 & 1 & -1 & 0 & 4 \\
Walking & 1 & 1 & 1 & 1 & 1 & -0 & 0 & 5 \\
\hline
\end{tabular}

However, by using trishaw, the total score is better as compared to using car. The total score for each heritage site is 2 out of 5 points. This is due to the time allocated for trishaw riding which is limited to 15 to 20 minutes only per ride and the high cost of using trishaw. However, using trishaw reduces the carbon footprint and at the same time increase local economy since the operators are locals.

In addition, cruising through Melaka River using River Cruise tour did not score high. This type of tour only allows tourist to appreciate the smell of the river, the sound of the boat and water splashing, the sights of water front activities, the sights of historical buildings along the river, historical bridge architecture and Kampung Morten's light on during night time. However, this method scores 2 out of 5 points in terms of appreciating historical architecture along the river banks as compared to car and trishaw.

Riding bicycle provides a high score too. The score is higher than the ones by car, trishaw and river cruising. Riding bicycle allows tourists to appreciate the urban sensory elements closely. The score is 4 out of 5 points. However, tourists have to pay more for a longer rental of the bicycles. Furthermore, riding along Jonker Street and Jalan Tukang Besi does not ensure or offer safety due to the presence of motor vehicles along these two streets. They also face problem when wanting to park their rented bicycles due to lack of bicycle parking bays.

Likewise, walking gives the best scores of all in which each site scores 5 out of 5 points. Walking allows tourists to appreciate the details of historical buildings along Jonker Street, Jalan Tukang Besi, Melaka River water front and Kampung Morten at their own sweet time. Furthermore, they can also stop over the souvenir shops and cafes along Jonker Street and Jalan Tukang Besi. In addition, walking within Kampung Morten allows tourists to enter the historical houses and actually view the interior design of these houses. Likewise, areas near St Paul's Hills and the $17^{\text {th }}$ century Dutch Stadhuys are limited to pedestrian walkway. This is a good effort by the local authority in giving the opportunities to tourists to appreciate the aesthetic value of the areas (Figure 4). 


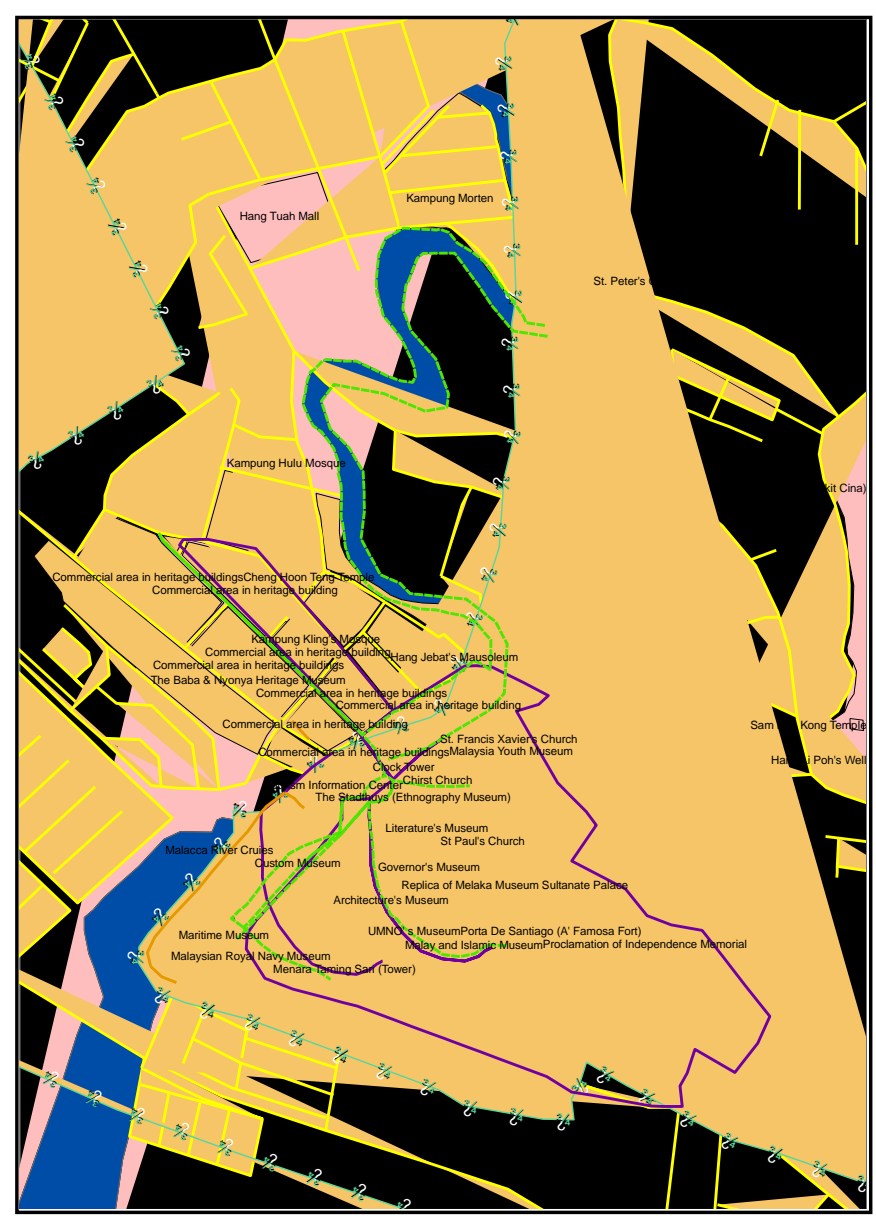

Figure 4: Types of Mobility in Melaka Historical City

Figure 4 confirms the results of participant observation. It shows spatially how accessible the types of mobility in the study area. Public bus routes and tour by car do not allow tourists to access their destinations easily. River cruise gives better experience. It allows tourists to experience all the four of urban sensory elements. However, it produces carbon footprint.

Trishaw and bicycle are two types of non motorized vehicles. Both give flexibility to tourists and produce zero carbon footprints. As shown in Figure 4, using a trishaw or a bicycle allows tourists to go anywhere they wish to go. Trishaw route is not fix and tourists can ask to be taken according to their needs. Using a bicycle also allows similar conditions. Walking is the best method that allows tourists to appreciate the urban sensory elements. Although walking distance is between 500 to 1000 meters, it allows flexibility to tourists to admire the richness of the elements. 


\subsection{Discussions and Conclusions}

The world heritage sites should be limited to walking, trishaw riding and bicycle riding. With that tourists are able to appreciate the aesthetics value of the heritage tourism products through the five senses. Moreover, congestion can also be avoided in these areas. Furthermore, tourists' safety while walking through the heritage sites is also assured. Nevertheless, fuel which is used for motor vehicles can be diverted for other uses. All these actions will reduce the amount of carbon being emitted to the environment surrounding the heritage sites. Furthermore, walking, cycling and trishaw riding allow tourists to choose activities they prefer to do such as shopping for arts and cultural products as souvenirs and stopping by a restaurant for a drink or local cuisine (Adkins et al., 2012; Mehta, 2008). The benefits of walking have been discussed in many studies including health and social related disciplines (Forsyth \& Southworth, 2008; Mehta, 2008). The outcome of this study adds to the current research in benefits of walking.

In order to facilitate walking and promote appreciation of built heritage through the sensory element, basic urban amenities and facilities such as benches and bicycle lanes and parking bay should be provided in order to allow tourists to take a short break while walking within the sites and to park their bicycles when they want to enter historical building (Adkins, et al., 2012). Furthermore, trees should be planted along the pedestrian walkway. Since the existing road can be used as pedestrian walkway, cost incurred in providing this facility can be reduced. Trishaw should be available at a longer time and at reasonable price. Tourists who use trishaw to tour around the city should be allowed to stop at whatever point they wish to do so. This will give them opportunities to explore the city for the first time.

While enhancing the appreciation of heritage, the elements of walking, cycling and trishaw will directly mitigate carbon emission to the environment, invoke economic boost to the trishaw and bicycle operators and promote healthy living to everyone. Thus, it is hope that Melaka local authority will consider these options which will guarantee better future for the next generation.

\subsection{References Cited}

Adkins, A., Dill, J., Luhr, G., \& Neal, M. (2012). Unpacking Walkability: Testing the Influence of Urban Design Features on Perceptions of Walking Environment Attractiveness. Journal of Urban Design, 17(4), 499-510. doi: 10.1080/13574809.2012.706365

Al-Sabhan, W. (2003). Approaches o developing a web-based GIS modelling tool: for application to hydrological nowcasting. PhD, King's College - University of London.

Andreanne. (2010, 6 July). Heritage Conservation for Tourism in Malaysia - Is it Possible? . Retrieved from http://planningpool.com/2010/05/heritage/heritage-conservation-tourism-malaysia/

Andriotis, K., Agiomirgianakis, G., \& Mihiotis, A. (2008). Measuring tourist satisfaction: A factor-cluster segmentation approach. Journal of Vacation Marketing, 14(3), 221-235. doi: 10.1177/1356766708090584 
Burchard, J. E. (1957). The Urban Aesthetic. Annals of the American Academy of Political and Social Science, 314 , $112-122$.

Chang, K. T. (2008). Introduction to geographic information systems. Singapore: McGraw-Hill Higher Education.

Chua, E. (2008, 8 September). Unesco accepts George Town and Malacca as World Heritage Sites, The Star Online.

Retrieved from http://thestar.com.my/news/story.asp?file=/2008/7/8/nation/21765425\&sec=nation

Coppock, J. T., \& Rhind, D. W. (2011). The history of GIS. Retrieved from http://www.wiley.com/legacy/wileychi/gis/Volume1/BB1v1_ch2.pdf

Dunlap, R., Schleicher, G., Keptner, T., \& Keptne, T. (2001). Moving Heritage Tourism Forward in Pennsylvania. Retrieved from http://www.rural.palegislature.us/heritage_tourism_whitepaper.pdf

Fornell, C. (1992). A National Customer Satisfaction Barometer: The Swedish Experience. The Journal of Marketing, 56(1), 6-21.

Forsyth, A. N. N., \& Southworth, M. (2008). Cities Afoot-Pedestrians, Walkability and Urban Design. Journal of Urban Design, 13(1), 1-3. doi: 10.1080/13574800701816896

Gössling, S. (2011). Carbon Management in Tourism: Mitigating the Impacts on Climate Change. Oxon: Routledge.

Heywood, I., Cornelius, S., \& Carver, S. (2002). An introduction to geographical information systems. Harlow, England: Pearson Prentice Hall.

Hoel, E., Gillgrass, C., \& McGrath, M. (2010). History of GIS: the commercial era: 1980 to 2010. Retrieved from http://proceedings.esri.com/dvd/uc/2010/uc-index/uc/workshops/tw_1187_3.pdf

Johari, M. H. Y. (2010). Satisfaction of site visit along the heritage trail in Melaka Town. In K. Din \& J. Mapjabil (Eds.), Tourism Research in Malaysia, what, which way and so what? (pp. 275-292). Sintok: Universiti Utara Malaysia Press.

McBoyle, G., \& Wall, G. (1987). The impact of CO2-induced warming on downhill skiing in the Laurentians. Cahiers de Geographie de Quebec, 31(82), 39-50.

McBoyle, G., Wall, G., Harrison, K., \& Quinlan, C. (1986). Recreation and climate change: a Canadian case study. Ontario Geography, 23, 51-68.

Mehta, V. (2008). Walkable streets: pedestrian behavior, perceptions and attitudes. Journal of Urbanism: International Research on Placemaking and Urban Sustainability, 1(3), 217-245.

Melaka Historical City Council. (2007). Special area plan: conservation area management plan of Melaka Historical City (Draft). Melaka Historical City: Melaka Historical City Council.

Oliver, R. L. (1980). A Cognitive Model of the Antecedents and Consequences of Satisfaction Decisions. Journal of Marketing Research, 17(4), 460-469.

OMT-WTO-BTO. (2003). Djerba Declaration on tourism and climate change Retrieved 6 July 2011, 2011, from http://scstsenvis.nic.in/djerba\%20dec\%20on\%20climate\%20change\%20and\%20tourism.pdf

UNWTO-UNEP-WMO. (2008). Climate change and tourism: responding to global challenges. Madrid: UNWTO.

UNWTO. (2007). Davos Declaration Retrieved 6 July, 2011, from http://www.unwto.org/pdf/pr071046.pdf

VanBlarcom, B. L., \& Kayahan, C. (2011). Assessing the economic impact of a UNESCO World Heritage designation. Journal of Heritage Tourism, 6(2), 143-164. doi: 10.1080/1743873x.2011.561858 
Wall, G., Harrison, R., Kinnaird, V., McBoyle, G., \& Quilan, C. (1986). The implications of climate change for camping in Ontario. Recreation Research Review, 13(1), 50-60.

Wisconsin Department of Tourism. (2011). Heritage tourism Retrieved 6 July, 2011, from http://www.preservationnation.org/issues/heritage-tourism/

Worboys, M. (1995). GIS: a computing perspective. London, UK: Taylor and Francis.

Yang, X., Tian, P., \& Zhang, Z. (2011). A comparative study on several national customer satisfaction indices (CSI) Retrieved from http://jgxy.usx.edu.cn/DAOM/114_XiaomingYang.pdf 